\title{
Bilingualism of Colombian Deaf Children in the Teaching-Learning of Mathematics in the First Year of Elementary School*
}

\section{El Bilingüismo de los Niños Sordos de Colombia en la enseñanza-aprendizaje de las matemáticas en el primer año de escuela primaria}

\author{
Olga Lucía León Corredor \\ Assistant Professor, School of Sciences and Education \\ Universidad Distrital Francisco José de Caldas, Bogotá, Colombia \\ E-mail: olleon@udistrital.edu.co \\ Dora Inés Calderón \\ Assistant Professor, School of Sciences and Education \\ Universidad Distrital Francisco José de Caldas, Bogotá, Colombia \\ E-mail: dicalderon@udistrital.edu.co
}

\begin{abstract}
This paper summarizes some results of the first ethnographic research study conducted in Colombia in three different elementary schools for deaf children in which bilingualism (sign-language and written-language) is starting to be emphasized. This study focuses on the teaching of mathematics in classrooms for deaf children using contexts proclaimed as bilingual. The participants in the study were first grade teachers. The analysis presented in this paper illustrates the struggles that teachers experience teaching arithmetic in such a context. The teaching of arithmetic using bilingualism requires three types of semiotic registers: sign-language and written-Spanish, and the Hindu-Arabic numeration system. The analysis indicates some puzzling teaching-learning issues interweaving language and mathematics. These issues are of linguistic and communicative, social and cultural, and cognitive and pedagogical nature.
\end{abstract}

Key words: deaf children, bilingualism, early arithmetic, Spanish, Colombian Sign-Language, semiotic systems, numerals.

\section{Resumen}

Presentamos resultados de la fase etnográfica del proyecto citado en la nota 1. Identificamos aspectos discursivos y matemáticos que inciden en la formación inicial de niños sordos en contextos de enseñanza de las matemáticas. Se realizó una observación en tres instituciones, en preescolar y primero de primaria de niños sordos, en contextos declarados como bilingües: lengua de señas colombiana (LSC) y castellano escrito (CE). Los participantes en el estudio fueron tres profesores de primer grado. El análisis evidenció dificultades que se presentan a los profesores cuando enseñan matemáticas a niños sordos; por ejemplo, enseñar aritmética requiere el uso y la articulación de, por lo menos, tres tipos de sistemas semióticos: la LSC, el CE y el sistema de numeración decimal indo arábigo. Este resultado es en un insumo para la formulación de currículos en las áreas de lenguaje y de matemáticas de primeros niveles de escolaridad de niños sordos y en soporte para un análisis didáctico que involucre aspectos de tipo lingüístico-comunicativo, socio-cultural, cognitivo, tecnológico y pedagógico, en la educación y en la escolarización de las personas sordas.

Palabras clave: bilingüismo, currículos de matemática, niños sordos, castellano escrito, lenguas de señas colombiana, sistemas de numeración

Received 10-04-2010 / Accepted 19-08-2010

* Research Article associated with the project titled Desarrollo de Competencia Comunicativa en Matematicas en Estudiantes Sordos, Código Colciencias: 250-2007, Departamento Administrativo de Ciencia, Tecnología e Innovación Conciencias y Universidad Distrital Francisco José de Caldas. 


\section{Introduction}

For the last ten years in Colombia, new policies and regulations regarding the education of the deaf have originated from the government. These regulations have evolved and currently their focus of attention is on the quality and effectiveness of formal education for the deaf. The current tendency emphasizes integration of deaf and hearing students ("Integration Policy" Decree 2082, November 18, 1996: Art. 3, 13, 14, 17; Prada, D. 1999). Although dictated by decree, integration has been interpreted in elementary and secondary schools in two different senses. One sense is space integration, meaning that deaf students from different elementary and secondary grades are sent to a school of hearing students. However, deaf students are placed in only one classroom specially designated for them with only one teacher to handle learning and cognitive difficulties at all grade levels. The other sense is deaf-hearing integration meaning that deaf and hearing students from the same academic grade are integrated in the same classroom with one interpreter to translate Spanish to Colombian Sign-Language (CSL) to facilitate communication.

From reports on the schooling process for the deaf (DANE, 2005; MEN-INSOR-FENASCOL, 1998) it is evident that-for most deaf childrenthere is little or no productive relationship between formal schooling and the quality of their education. Regarding mathematics learning in particular, the development of communicative skills in mathematics is minimal. Mathematics learning is associated with the simultaneous development of discursive skills (in particular, discursive-process skills for the interpretation and production of mathematical texts) and visualization processes, both of which enable learning abstract concepts with no ostensible counterparts, based on the combined use of different semiotic systems (SS). In basic arithmetic, natural languages support reasoning processes that are simultaneously anchored in oral or written speech and other SS, such as gestures, pictures, algebra or other symbolic numeration systems (Roman, HinduArabic, finger, dot numerals,etc.). ${ }^{1}$ In particular, in the learning of arithmetic, dot numerals play an important role for the non-hearing-impaired as well as for deaf students to grasp the notion of natural number. Research about the mathematicslearning of the deaf reveals that it is necessary to cope with the development of sign-language for mathematical communication (Augusto, et al., 2002).

\section{The development of communicative skills in the deaf: research context}

The theoretical framework of the research study attempts to address five aspects related to the understanding of the teaching and learning of mathematics to deaf children: the identification of communicative skills in learning mathematics, the importance of the socio-cultural perspective of language in conceptual development, schooling for the deaf; the importance of bilingualism in the learning processes of deaf children, and the development of arithmetic processes in deaf children.

The identification of communicative skills in learning mathematics

One fundamental factor in the acquisition of mathematical communicative skills is the development of visualization as a form of internal representation using mental structures and diagrams. Visualization requires both perception (sensory-motor activities) and reflection (cognitive activity). We have a number of diverse forms of perception (sight, touch, taste, hearing, and smell, as well as other somato-sensory inputs) as well as diverse forms of reflection (based on interactions of the individual with the environment). From this point of view, there is a 
basic role played by visualization when it comes to building mathematical knowledge and basic intuitions (e.g. the notions of natural numbers and geometric shapes).

In the specific case of arithmetic, it is possible to identify three fundamental stages that allow a very productive individual-environment interaction when formulating those questions: i) the construction of quantitative relations; ii) the development of different representative forms for quantity communication and quantity management, and iii) the development of number sense based on multiple experiences with quantity. These three stages establish various semiotic processes that ultimately let visualization become a source of interpretation and production of external semiotic representations (SR's) determined by the use of semiotic representation registers (SRR's) aimed at situation modeling (León, 2005). ${ }^{2}$ Standing on this horizon of communicative-skill arrays, discursive processes for the interpretation and production of texts necessary to communicate in mathematics acquire a wider semiotic dimension that includes everyday language usage as only one of the several SSR's involved in the development of visualization.

The importance of the socio-cultural perspective of language in conceptual development

In order to understand the role of language in education, we chose two starting points. The first fully assumes the semiotic, symbolic and linguistic nature of human actions. This stance involves placing ourselves within the framework of socio-cultural language-and-thought studies (Vigotsky, 1981; Oléron, 1985; Rogoff, 1993), where human social experience is considered to be essential for individuals to develop their own knowledge and thinking. The second is a semiotic proposal about languages (Halliday, 1982), where language is regarded as "a potential for behavior within a meaning potential". Language development through the mediation of CSL and written Spanish implies acquisition and use of syntactic, semantic, and pragmatic rules for speech and register ${ }^{3}$ production, as well as rules for interactive-socio-cultural logic based on a polyphonic-dialogic view (Bajtin, 1982; Martínez, 1997, 2001, 2005; Calderón, 2005, in press). Such a view makes it necessary for both teachers and students to identify different discursive procedures used in the classroom, including those associated with specific subjects of study, for example, school mathematics (Calderón, in press). Hence, developing reading, writing, speaking and listening skills within academic contexts (mathematics in our case), increasing lexical repertoire related to each subject (school mathematics in our case), and learning and differentiating narrative productions, explanations and justifications appropriate to each subject (and mathematics in particular) become imperative for the socio-cultural development of every student.

\section{The schooling for the deaf}

With regard to this aspect, the following two streams were identified in the organization of a specific school for the deaf:

- The oral stream (which initially occurs together with a monolingual stream). In this stream, schooling begins from pure major tongue verbalism and attempting oralization of every deaf student in the dominant spoken language. Later it might extend to different modalities, including sign-language in environments outside regular teaching processes (Lane, 1984; Van Cleve and Crouch, 1989; Erting, et al., 1994; Oviedo, 2001). In this stream, deaf students are integrated into schools alongside a majority of hearing children, making it mandatory for profoundly deaf students to gain knowledge on all areas of study, and at the same time, acquiring the spoken language within an atmosphere where 
everything develops around the major tongue. Some findings indicate that it is precisely in mathematics learning where a growing gap between non-hearing-impaired children and the deaf is more evident (Costanzo, 2001).

- The bilingual stream, based on studies such as Fernández Viader, et al., (1998), Rodríguez (1992), Marchesi (1995), and others, starts by appreciating the use of sign-language as a full code (hence, as a major tongue along with the dominant spoken language), and also the simultaneous use of alternative communication systems in order to create conditions to learn social rules and develop basic cognitive abilities.

Bilingualism in deaf children requires both the use of sign-language used by the deaf community and the use of written-language used by the majority of the people. The written-language is learned by deaf children in a written and/or spoken form whenever possible. Both languages play different roles in different children. Some children mostly use sign language, others mostly use orallanguage, but some are able to equilibrate both languages depending on the development of their educational, social, and family contexts.

Bilingualism, in this sense, comes with a series of factors that make the situation more complex. One of these factors is the relation between the levels of deafness and the interactions between sign-language and orallanguage. In this interaction appear: 1) three linguistic modalities (oral, written, visual and gestural); 2) two production systems (sound and oral articulation, hand-expression, and corporal gesture articulation); 3) two perception systems (hearing and vision). This factor alone implies in deaf children different types of bilingualism and biculturalism. The bilingualism in deaf children seems to be similar to the bilingualism of children speaking two languages.
Like other bilingual children, deaf children live in two worlds (the listener world and the deaf world) and they use two languages (Grosjean, 1999). It's important to emphasize that bilingualism in deaf children should be studied more in depth due to the factors mentioned above affecting the interaction between sign-language and written-language. However, from a didactical point of view it is relevant to consider that in deaf children the two languages constitute natural channels for their communicative and linguistic development. This is why it is necessary to learn the particular aspects of sign-language and written-language to be able to communicate with and teach deaf children. Deaf children learn the complexity of the number system through both languages as indicated by the analysis of the data presented in later sections of this paper.

In Colombia, bilingualism in deaf children is a pedagogical responsibility because the only option they have to develop both languages (signlanguage and written-language) is through the school. The first six years of their lives are lived in the world of their parents who do not speak oral language and do not use or understand signlanguage. During the first formative years in their lives emerge emotional, social, and educational problems from these early years.

\section{The importance of bilingualism in the learning processes of deaf children}

Throughout history, deaf people have been discriminated with regard to their rights and also with regard to their access and enjoyment of social interaction and education. The education of deaf children has been framed as "special education" and not as formal education (Skliar, et al., 1995, Alegría et.al., 2002, Ramírez and Castañeda, 2003). National and international policies have the tendency to consider deafness as a disability. For this reason, education and socio-cultural treatment of the deaf have been classified as 
clinical situations and treated with therapies to make the deaf a listener and an oral speaker in the listener's world. That is, in socio-cultural and educational situations, the therapeutic treatment of deaf persons is to implement their oral language to incorporate them in the community of listeners without respecting their more natural access to sign language.

Another concept of the deaf person as different from their disability emerges and they are taken as part of the social cultural discourse. That idea belongs to Ainscow (1999), Vlachou, (1999), and Schalock (1999). According to the latter author, the identification of this form of the disability is a fruit of the interaction between the person and the environment in which she or he lives, and is why it's important to change the point of view about a deaf person in order to increase her or his quality of life. This means giving deaf students autonomy, social acceptance, and the same opportunities and abilities to develop.

During the last 10 years, Colombia has had a law that demands schools to fulfill the social education of all citizens. Studies conducted by different national institutions indicated the majority of deaf people do not go to school and are illiterate. For example, studies conducted by the Administrative Department of National Statistics (DANE, 2005) shows that $88.7 \%$ of the deaf population doesn't go to school. In addition, the National Ministry of Education, the National Institute for Deaf People, and the National Federation for Colombian Deaf (MEN-INSOR-'s study Fenascol) conducted a study in 1998 that indicates that $51.4 \%$ of the deaf population is illiterate.

However, this phenomenon is not inherent to Colombia. International surveys show two bewildering issues: 1) most deaf children never reach a basic reading level (Marchesi, 1995; Allen, 1986; Ascencio, 1989; Lewis, 1996; August et. al., 2002); 2) although deaf children go to school, $80 \%$ of the deaf teenage population is illiterate due to difficulties of linguistic origin (August et. al., 2002).

The previous national and international reports show a sequence of serious problems in the education of the deaf population. Because of reasons given above, the school alone cannot satisfactorily answer the challenges of educating deaf children; the general society must contribute. Deaf people are destined to be unequally treated in fields of social performance, including the labor force, the income field, the affective field, and in social relations in general.

In the field of education, complexity increases due to the lack of bilingualism of teachers of deaf students and deaf students themselves in oraland sign-language. In Colombia more specifically, mathematics teachers do not have training in sign-language. It is also important to consider how to express mathematical concepts in oraland sign-language (in our case Colombian SignLanguage, CSL). We have mathematics teachers classified in two categories: 1) those who know sign-language but do not have mathematical formation; and 2) those who do not know signlanguage but have mathematical formation. The teachers in the second category need to have an interpreter (i.e., a person who knows oral- and sign-language). However, in these cases, the interpreter's repertoire is sometimes limited in both languages in order to communicate to deaf students mathematical concepts express orally and translated into sign-language. It is for this very reason that bilingualism in oral- and signlanguage is an essential and not a substitutive component for the conceptual development of deaf children and adults.

At the end of the $20^{\text {th }}$ century, the spread of models known as "bilingual/bicultural" and the emphasis on the social and anthropological conceptions of deafness were the most relevant aspects of change in the situation of deaf 
individuals and communities (Skliar, Massone and Veimberg, 1995). At any rate, identity construction processes do not depend solely on having more-or-less serious biological limitations, but mainly on complex cultural, social, historic and linguistic relationships. In this direction, studies that have considered sign-language as a first language and therefore conventional spoken languages as second languages (Portilla, Bejarano and Cárdenas, 2006; Cruz, 1999; and Ramirez, 2002), together with research on written-language teaching as a second language (Quiñonez, Ramírez and Valbuena, 2000, 2006; MENINSOR, 2003; Tovar, 2004), have contributed to the design of a series of pedagogical orientation booklets and innovative support materials for deaf-children teachers about basic processes, principles and workspaces. These booklets are aimed at teaching Spanish as a written language (from kindergarten to the fifth grade) within the framework of a form of bilingual-bicultural education for the deaf, in which Colombian Signlanguage (CSL) is the major tongue.

\section{Development of arithmetic processes in deaf children}

Research into arithmetic teaching and learning often highlights aspects such as calculation and problem-solving processes in deaf children. In studies like Mulhern and Budge (1993); Moscoso, Orjuela, and Portilla (2004); Mousley and Kelly (1998); Frostad and Ahlberg (1999), and others, emphasis is placed on the convenience of creating a mechanism that will allow deaf students to understand the meaning of the linguistic elements involved in the wording of a problem before actually attempting to solve it. In the work of Nunes and Moreno (2002), the emphasis is placed on the need to suggest the use of either figure-like or table-like SRR's as complementary registers to the natural-language register in order to develop arithmetic processes for the deaf.

A few studies in mathematics education that reframe the development of arithmetic skills
(Gómez, 1993; Puig and Cerdán, 1988; Vergnaud, 1988; Poveda, 2000; Kamii, 1994) establish three minimal abilities: i) formulate and solve problems whose wording involves identification of relations among quantities, ii) identify relevant operations suitable for modeling the arithmetic situation formulated in those problems and, iii) represent numeric quantities and so perform algorithms of addition, subtraction, multiplication and division to find the results of those operations. These abilities necessarily involve complex semiotic and semantic processes connected with reading and writing in the major tongue and in other SRR's, mainly in the Hindu-Arabic numeration system.

\section{Methodology}

We adopted a simplified ethnographic methodology for the observation of a few firstgrade classrooms for the deaf in three different schools. Broadly speaking, we considered two constituent elements that are part of the environment within which the phenomenon "number system teaching for the deaf" occurs: i) the settings that were considered when studying the phenomenon, in this particular case, three schools dealing exclusively with deaf people, and ii) the main actors in the phenomenon analyzed, in this case, 16 deaf children, and, as linked actors, three teachers and two linguistic models. ${ }^{4}$ The curricular level for the observations was the first grade.

Only the teaching phenomenon was observed and analyzed. Because of the ethnographic methodology adopted, we observed the entrylevel behaviors in arithmetic by the children involved in the classroom interactions but did not attempt to evaluate the actual learning produced by those interactions.

Three types of criteria oriented the process of observation of the educational action in three educational institutions. The first criterion was structural: the knowledge of both CSL 
and arithmetical processes. It was applied for the selection of non-participant observers. The second criterion was didactical: class organization, organization of the teachingunit, and general use of signs (oral, written, or gestural). It was applied for the selection of the units of observation in the mathematics class. The third criterion was institutional: distinguish types of school institutions. It was applied for the selection of the types of mathematics classrooms according to the institutions.

Diagram 1 Observation criteria

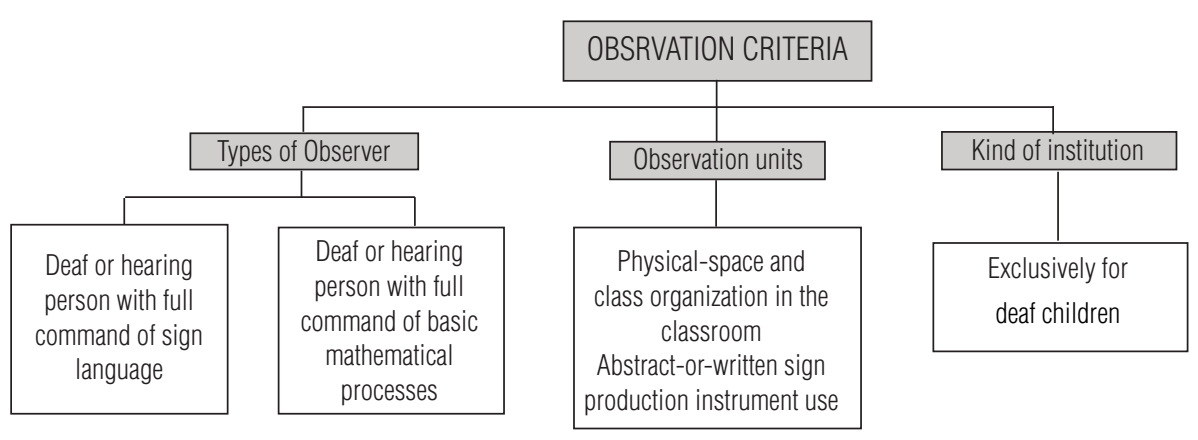

This is an analytical-inductive ethnography, which benefited from the comparative analysis of the different categories according to their settings and actors.

The sources of data were supplied by four sources of information: 1) the protocol of the nonparticipant observer; 2) nine classroom videos; 3 ) three teacher interviews; 4) drawings and writings produced by the children.

The four sources of data were analyzed using two techniques. The first technique was the analysis of content conducted by three teaching experts: one in sign-language, one in written-language, and another in mathematics. Each expert performed his/her own analysis of the content and each delivered a structure of emergent categories. The second technique was the triangulation of the above mentioned emergent categories to obtain a structure of categories for the analysis of the teaching of mathematics of deaf children. Diagram 2 illustrates the elements of observation and analysis.

Diagram 2 Observation and analysis

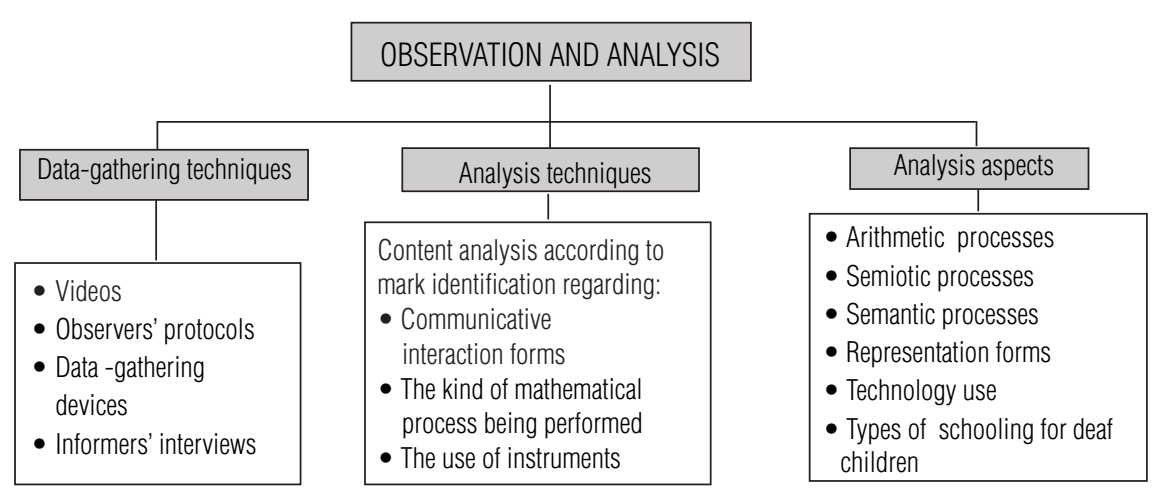


As a result-regulation factor, a triangulation of the different categories was conducted separately by each researcher for each one of the data sets obtained. Such procedure was carried out due to the fact that the research team consisted of a mathematician, a linguist, and a deaf observer. Each of them analyzed the full corpus from the perspective of their own field of expertise taking into account the different initial and emergent categories.

From the perspective of the linguistic field it is important first to analyze the structure of the written-language used in the bilingual praxis (in our case the Spanish language) which is the second language for the deaf community. The structure of the written-language is reflected in the linguistic forms of mathematical concepts (i.e. their lexicon and particular grammar). Second, in the discursive forms (i.e. enunciative forms) of the subjects who take part in the mathematical interaction (i.e., teacher and students), and finally, in the representational forms (i.e. semiotic representation registers, SRR) used in numeric, algebraic, and geometric contexts.

The structure of Colombian Sign-Language (CSL) is also analyzed as a complement to the previous analysis. This analysis also identifies linguistic, discursive, and representational forms. The CSL is constituted by signs using hands, body gestures, and facial expressions, all of which were visually perceived. CSL has its own grammatical structure different in its functioning from the Spanish language. However, CSL has the same validity as the Spanish language to perform communicative functions.

The mathematical analysis identified children's actions on and about quantities, semiotic conditions to perceive, compare, and operate with quantities, and arithmetical processes developed in classroom interactions. The analysis of mathematical concepts involves, among other things, sensorial aspects (visual, hearing, tasting, smelling and touching), linguistic aspects (interpretation and production of signs, production of meanings), cognitive aspects (to differentiate between objects that are going to be counted and objects used to count), cultural aspects (conventional forms in counting using number representation or fingers), and mathematical aspects (relation between numbers, correspondence, colections, sets, order, third kind relations).

In addition to the analyses mentioned above, a second round of triangulation was conducted after the first round of analyses in order to attain a valid construction and refinement of the initial emergent categories.

\section{Results}

A reconstruction of first-grade mathematics lessons in schools for deaf children was identified from three different types of results. These results are described and explained in the following sections.

\section{Results in the school environment}

The teaching phenomenon was determined by different types of teachers, students, and institutions. Tables 1, 2, and 3 present characteristics attributed to the main participants (teachers, students, and institutions) in this study.

Multi-grade classrooms sharing at least two school levels (kindergarten and first grade) were identified as the school setting of most deaf children. In every classroom of two of the institutions, deaf children with or without additional limitating conditions were integrated with hearing children with additional limiting conditions (cerebral palsy and visual or mental impairment).

From another perspective, three different ways of schooling for the deaf were identified: 
Table 1 Types of teacher identified

\begin{tabular}{|l|l|}
\hline $\begin{array}{l}\text { Deaf teacher with technical } \\
\text { training in teaching }\end{array}$ & $\begin{array}{l}\text { Proficient in Colombian Sign Language (native CSL user). No previous training in school } \\
\text { mathematics. Good development of CSL. Low mathematical development. Direct interac- } \\
\text { tion with children. }\end{array}$ \\
\hline $\begin{array}{l}\text { Hearing teacher trained } \\
\text { in CSL accompanied by a } \\
\text { linguistic model }\end{array}$ & $\begin{array}{l}\text { Not proficient in CSL. No previous training in school mathematics. No direct interaction } \\
\text { with children. The linguistic model, with good development of CSL, is the one who as- } \\
\text { sumes direct interaction with children and also plays a protagonic teacher role. }\end{array}$ \\
\hline $\begin{array}{l}\text { Hearing teacher with } \\
\text { training in Special } \\
\text { Education }\end{array}$ & $\begin{array}{l}\text { Acceptable level of CSL and curriculum knowledge but no previous training in school } \\
\text { mathematics. Direct interaction with children. Occasionally accompanied by a linguistic } \\
\text { model. }\end{array}$ \\
\hline
\end{tabular}

Table 2 Types of student identified

Deaf, with or without implants, not under conditions of other cognitive or physical limitations

Deaf, under conditions of other cognitive or physical limitations
Children between 6 and 9 years of age, with some knowledge and command of CSL. They do not read or write Spanish.

Children between 6 and 11 years of age, under additional conditions such as cerebral palsy, mental impairment, blindness or family neglect. Very poor knowledge and command of CSL. They do not read or write Spanish.

Table 3 Types of institution

\begin{tabular}{|l|l|}
\hline Private/government & $\begin{array}{l}\text { Two private and one government school. The two private schools are essentially schools in- } \\
\text { tended for deaf and hearing-impaired children. Their funds come from tuition fees, national } \\
\text { and international donations, and public subsidies for students. The public school is an ex- } \\
\text { perimental social-educational research institution that has not yet been officially chartered. }\end{array}$ \\
\hline Religious/secular & $\begin{array}{l}\text { Two secular institutions and a religious one. The religious school instills its philosophy into } \\
\text { every single sphere of its institutional life; it demands a religious commitment from teachers } \\
\text { and students, and organizes rituals in school and in after-school activities related to its } \\
\text { beliefs. }\end{array}$ \\
\hline
\end{tabular}


- There are few educational institutions in Colombia that deal exclusively with the deaf. Among them are the schools Sabiduría, Filadelfia, and ICAL and all of them in Bogotá, the capital city.

- Ordinary integrated institutions, which deal mainly with non-hearing-impaired students, deaf students "integrate" into the mainstream classrooms. Such institutions offer speech-therapy services and curriculum reinforcement, often in specialized classrooms. In many of these institutions, integration classrooms have also been created, where deaf children receive special attention and the help of an interpreter (Sánchez,1990).

- Special integrated institutions, where children with different kinds of impairment are organized in different classrooms available. Basically, institutions like these rely on specialist teams. They adapt the curriculum itself as well as its access elements (Sánchez, 1990).

Given the philosophical and methodological implications that lie in the different demands imposed by having so many different trends and types of schooling simultaneously, these findings regarding schooling for the deaf provide serious discussion and reflection points for our study and others to follow.

\section{Results based on the presence of mathematical contents}

The teaching phenomenon was determined by different types of teachers, students, and institutions.

In all three institutions, teaching activities linked to counting were identified. When analyzing initial counting-related processes, it was found that students showed a lack of command of aspects such as: one-to-one correspondence, stable ordering, and cardinality. In particular, deaf students did not seem to realize that the order of the addends is not important when counting discrete quantities, even in case of groupings of less than 20 dots or items. Students' difficulties identified in the development of counting can be mainly attributed to semiotic variables involved in this process. The curricular adaptations made for the first grade, when referring to the natural number system, still remained well below the current official curricular standards for this grade.

There are four co-existing semiotic representations of natural numbers: verbal written Spanish numerals (written in English in the left column of Diagram 3), gestural CSL hand numerals, visual dot numerals, and Hindu-Arabic decimal numerals.

Although there seems to be a wealth of semiotic representations of numbers, the different SRR's are used regardless of explicit management conditions that would allow flexible conversions from one into another. Except in the HinduArabic decimal SRR, in the other three SRR's the given semiotic representations are not subject to treatments.

\section{Results on arithmetic processes and the use of technology}

Abacus and domino-like cards were used. Neither computers, calculators, nor other kinds of didactic-support instruments were used.

\section{Results based on the development of discur- sive processes}

In general, the development of CSL-mastery by all children seems to be fairly poor in the three observed settings, even for direct communication interchanges, and much poorer (even in CSLtrained teachers) for interchanges that demand more complex discursive processes in the academic disciplines, especially in mathematics.

This is partly due to current limitations in the mathematical lexicon of CSL, and in the available discursive resources both to talk about mathematics and to do mathematics with the help of CSL. 


\section{Diagram 3}

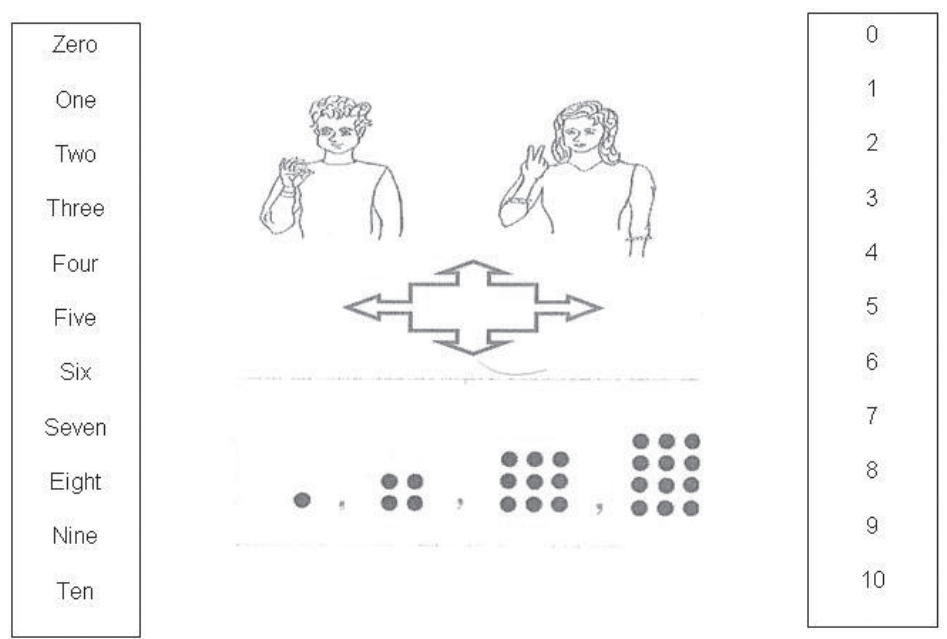

Based on these findings, doubly problematic circumstances arise that have no short-term remediation: the discursive command of CSL by teachers and the linguistic development of CSL resources in the field of mathematics.

In one case, the hearing-teacher's lack of command of CSL resulted in a shift of the teacherstudent interaction towards the accompanying linguistic model. In other cases, children were provided with very little mathematical vocabulary. Regarding the development of CSL in the lexical field related to mathematics, both the CSL limitations and the teacher's limitations resulted in a very reduced availability of signs, words or other expressions related to mathematical objects, relations, operations and experiences. As a result, even when taught by a CSL-proficient deaf teacher, children were provided with very little vocabulary directly related to the subject.

Classroom observations indicate two kinds of interactions in sign-language:

1) The class with a deaf teacher was characterized by a highly structured teacher-student interaction based on a question-answer scheme. There was almost no discursive interaction between teacher and student and among the students themselves. Consequently, there was very little lexical development and very few opportunities for narrative or explanatory development on the part of the children or the teacher. An analysis of a teaching episode from a CSL classroom supports the above assertion. This episode was translated into Spanish from CSL. In the following transcript $T$ stand for teacher and the numbers on the left keep track of the minutes elapsed on each of her interventions.

0:34 T: [Teacher gives instruction and does more questions and instruction later on].

Look we are going to practice addition, we are going to practice, you know addition, addition, addition.

9:25 T: What's going on? Already you finished, finished. So, erase and do it again, it's not complete.... You erase.... Erase again and do it again and again. No, no, look.

16:58 T: What's that? Eight?

17:09 T: Seven, seven, it does not look, seven, yes, it looks ...

17:26 T: Let's see, already, already, 
17:44 T: Seven ,ahhh, something is missing.

17:58 T: I don't understand, you're solving everything? Let me see.

18:09 T: seven, seven do not look, look.

18:20 T: Already, to seeing. Not, this not

18:34 T: Why it? Why one, why, why one, because, look one, two, three, four, five, six, seven, eight, nine, already nine, well.

18:56 T: So, no.

19:04 T: Ok, work, gossip and gossip, not?, work. Already it is working.

$\mathrm{J}, \mathrm{C}$ and $\mathrm{M}$ at all, only speaks, speak and speak, no!

2) The class with teacher listener and linguistic model (native of CSL), was characterized by a structure of the interaction and development of activities in the classroom project. In this case, a relationship among the teacher, the linguistic model, and the students was observed. This type of triadic relationship decreased teacherstudent interactions (because the teacher does not have enough competence in CSL) while increasing the linguistic model-student interactions (because model and student are deaf). This increasing interaction decreases the possibility of a discursive academic development on the part of deaf children that the teacher could have developed intentionally or unintentionally (e.g. the development mathematical lexicon, relationships in the solution of mathematical problems, and mathematical expressions).

\section{Discussion}

Specific mathematical training for teachers who interact with deaf children arises as a relevant aspect when it comes to communicating and using concepts of quantity from an arithmetic perspective. Teachers' lack of knowledge about semiotic and discursive aspects of different SRR's related to arithmetic, which allow using diverse semiotic representations of natural numbers (linked at least to sign-language, to written Spanish, or to the written Hindu-Arabic numeric system), along with their different treatments and conversions, generates very few degrees of freedom for teacher's didactic practice whenever children have difficulty counting and handling numbers operatively, regardless of which numeration systems is used. Groups of dots are used merely for counting them like static tokens, not even as a fourth SRR, which would allow both internal treatments and conversions to or from the other three SRRs.

Lack of consistency between the three numeration systems, sign-language and written Spanish with each other and with standard decimal Hindu-Arabic numerals, makes it more difficult for children to understand arithmetic identification and communication of quantities in various contexts. However, the higher levels of consistency between the current SRR of signlanguage numerals and the Hindu-Arabic decimal numerals do offer didactic alternatives to explore. More detailed knowledge about these levels of consistency would allow the design of heuristic practices and problem-solving situations that are relevant to the development of arithmetic processes, like counting and performing the various numeric operations by the deaf. In other words, the identification, study, and practice of consistency aspects between the meaningful units of every available SRR must be a priority in order to raise the level of counting, problem solving and number sense in deaf children.

A classroom environment including children that require other special educational assistance in addition to hearing-impairment aids makes 
much heavier demands on teachers and students. These additional demands increase the difficulty of teaching mathematics to them. Student-student and teacher-student communication become more complex for any task, and such complexity has an impact on communicative isolation at an age at which communicative interaction plays an important role in language development for the deaf in all areas, and not only in mathematics.

The absence of computers, calculators and other mathematically-structured support devices results in very little presence of student-initiated exploration processes on semiotic representations and in student-to-student mathematical communication. Interaction among children and instruments could generate rules for the use and sharing of those devices, for trial-and-error invention of notations and algorithms, and for refined discursive developments that would foster mathematical reasoning. These aspects are now reduced to imitation only.

\section{Conclusions and recommendations}

Knowledge of school phenomena in fields that have not been widely explored in terms of the didactics of mathematics in Colombia, such as the teaching of arithmetic to deaf children, is a necessary starting point for new developments in mathematics education for children with special educational needs. This is only a preliminary study of the current conditions of a few institutions where initial mathematics teaching for the deaf is now being implemented. In spite of their limitations, these ethnographies showed the complexity of the educational system and its boundaries when it comes to including or excluding children with this types of disabilities.

A deaf-child school environment is very valuable to conduct research processes in order to design more effective pre-service and in-service teacher education in the area of mathematics for deaf children.
Communications about mathematical content carried within sign-language in richer discursive practices beyond mere information sharing would be one conditions to support the development of arithmetic knowledge as well as to educate individuals to develop communicative and reasoning skills, not only in mathematics. This development in all areas of school study would find a privileged field in the initial arithmetic teaching from first grade on if teachers appreciate the necessary links between the different SSR's with which natural-number arithmetic is practiced and the multiple affordances of treatments within each SRR and conversions from one to another.

The results of this ethnography also show that the educational system in Colombia is still in great debt with regard to mathematics education for the deaf. This can be seen in school settings, in the training of teachers, in the availability of interpreters and linguistic models, and in the contents of the different curriculums and their scopes, as the latter are far less ambitious for the deaf than for the non-hearing-impaired population.

The deaf observer in the study made two important recommendations for the teachers of deaf children. The first recommendation is the necessity for teachers to develop bilingualism in oral- and sign-language in a disciplinary field for didactical purposes. The second recommendation is the necessity to give a didactical preparation to teachers of deaf children to enable them to design mathematical tasks and activities to allow knowledge to be translated into their daily lives while developing communicational skills.

\section{References}

Alegría. J. (1985) Simposio Logopedia. Madrid (España): Alianza Editores.

Allen, D. (1986). Patterns of academic achievement among hearing impaired American Annals of the Deaf, pp. 122, 62-69. 
Allison, C., Del Sordo, V., Goldman, A. Assitive Technology for All. En: Journal de Disability Policy Studies. Vol.14/No.4/2004/pp.194-203.

Ainscow, M. (1999) Understanding the Development of Inclusive Schools. Falmer.

Augusto, J. M., Adrián, J. A., Alegría, J. \& Martínez, R. (2002). Dificultades lectoras en niños con sordera. Psicothema, 14(4), 746-753.

Bajtín, M. (1982). Estética de la creación verbal. Mexico: Siglo XXI Editores.

Biber, D. (1995). Dimensions of register variation: A crosslinguistic comparison. Cambridge, UK: Cambridge University Press.

Calderón, D. (2005). Dimensión cognitiva y comunicativa de la argumentación en matemáticas. Tesis doctoral no publicada. Cali: Universidad del Valle.

(in press). El lenguaje en las matemáticas escolares. En: Perspectivas en la didáctica de las matemáticas. Publicación del Énfasis en Educación Matemática. Doctorado Interinstitucional en Educación. Bogotá: Universidad Distrital Francisco José de Caldas.

Costanzo, A. (2001). Trabajo comparativo del aprendizaje sistemático de las matemáticas entre el segundo ciclo de la EGB normoyente y el segundo ciclo de la EGB oralista para niños sordos. Tesis de licenciatura no publicada. Rosario, Argentina: Universidad Nacional de Rosario.

Cruz, L. (1999). El bilingüismo de los sordos. Instituto Nacional para Sordos (Documento $n^{\circ}$ 1526). Bogotá: INSOR.

Dane (2005). Resultados del Censo General de Colombia 2005. Bogotá: Departamento Nacional de Estadísticas DANE.

Duval, R. (1995). Sémiosis et pensée humaine. Bern, etc.: Peter Lang. (Spanish translation: Semiosis y pensamiento humano). Cali: Universidad del ValleIED-GEM, 1999).

Erting, C., Johnson, R., Smith, D. \& Snider, B. (Eds.). (1994). The Deaf Way : Perspectives from the International Conference on Deaf Culture. Washington, DC: Gallaudet University Press.

Fernández Viader, M. Del P., \& Pertusa Venteo, E. (1996). El valor de la mirada: sordera y educación. Barcelona: Publicacions i Edicions de la Universitat de Barcelona.

Frostad, P., \& Ahlberg, A. (1999). Solving story-based arithmetic problems: achievement of children with hearing impairment and their interpretation of meaning. Journal of Deaf Studies and Deaf Education, 4(4), 283-293

Gómez, B. (1993). Numeración: evolución y comparación de sistemas. En: B. Gómez, Alfonso, Numeración y cálculo (pp. 31-59). Madrid: Síntesis.

Grosjean, F. (1999). Le bilinguisme: une compétence communicative à part entière. Educateur Magazine, $12,18-21$.

México: Fondo de Cultura Económica. (Obra original publicada en inglés en 1978).

Insor (1996). Caracterización laboral, socioeconómica y educativa de las personas sordas afiliadas a FENASCOL. Bogotá: INSOR.

Kamii, C. (1994). Reinventando la aritmética II. (2a ed.). Madrid : Visor.

Lane, H. L. (1984). When the mind hears: A history of the deaf. New York : First Vintage Books.

León, O. L. (2005). Experiencia figural y procesos semánticos para la argumentación en geometría. Tesis doctoral no publicada. Cali: Universidad del Valle.

Lewis. S. (1996). The reading achievements of a group of severely and profound impaired school leavers educated within a natural aural approach, The British Teachers of the Deaf, 20, 1-7.

Marchesi, A. (1990). La educación del niño sordo en una escuela integradora. En A. Marchesi, C. Coll y J. Palacios (Comps.), Desarrollo psicológico y educación. Madrid: Alianza

(1995). El desarrollo cognitivo y lingüístico de los niños sordos. (3 ${ }^{a}$ reimpresión). Madrid : Alianza Psicología.

Marschark, M. (1993). Psychological development of deaf children. Oxford, New York, etc.: Oxford University Press.

Martínez, M. C. (Comp.). (1997) Discurso, proceso y significación: Estudios de análisis del discurso. Santiago de Cali: Universidad del Valle.

(2001) Aprendizaje de la argumentación razonada. Santiago de Cali: Cátedra UNESCO Universidad del Valle.

(2005). La argumentación en la dinámica enunciativa del discurso. Santiago de Cali: Cátedra UNESCO - Universidad del Valle.

Men-Insor-Fenascol (1998). Orientaciones para la Integración escolar de estudiantes sordos. Santa Fe de Bogotá: MEN. 
Men-Insor (2003) Requerimientos pedagógicos, administrativos y de servicios de apoyo para la escolarización de educandos sordos Usuarios del castellano oral en instituciones educativas. Bogotá: MEN-INSOR.

Moscoso, H.; Orjuela, M., \& Portilla L. (2002). Los procesos de visualización en la identificación de relaciones multiplicativas por parte de estudiantes sordos. Tesis de Especialización no publicada. Colombia: Universidad Francisco José de Caldas.

Mousley, K., \& Kelly, R. (1998). Problem-solving strategies for teaching mathematics to deaf students. In: American Annals of the Deaf, 143(4), 325-336.

Mulhern, G., \& Budge, A. (1993). A chronometric study of mental addition in profoundly deaf children. Correspondence to Gerry Mulhern, School of Psychology, The Queen's University of Belfast, Belfast, Northern Ireland.

Nunes, T., \& Moreno , C. (2002). An intervention program to promote deaf pupils' acheivement in mathematics. Journal of Deaf Studies and Deaf Education, 7(2), 120-133.

Oléron, P. (1985). El niño y la adquisición del lenguaje. Madrid: Morata.

Oviedo, A. (2001). Apuntes para una gramática de la Lengua de Señas Colombiana. Cali: Universidad del Valle-INSOR.

Pérez, Y. \& Tovar, L. (2005) Análisis de la interacción verbal mediada por una intérprete de lengua de Señas Venezolana en el aula de clases bilingüe- bicultural para sordos. Retrieved 2010-02-21 from http://www. cultura-sorda.eu/7.html

Puig, L. \& Cerdán, F. (1988). Problemas aritméticos escolares. Madrid: Síntesis.

Portilla, L., Bejarano, O. \& Cárdenas, M. (2006). Educación bilingüe para sordos- etapa escolar. Orientaciones pedagógicas. Documento No. 1 INSOR. Bogotá: MEN-Revolución Educativa.

Poveda, M. (2000). Matemática a la medida de los niños. Bogotá: IDEP.

Quiñónez, E., Ramírez, P. \& Valbuena, A. (2000). Requerimientos pedagógicos, administrativos y de servicios de apoyo para la escolarización de educandos sordos Usuarios del castellano oral en instituciones educativas. Bogotá: MEN-INSOR.

(2006). Representaciones sociales de un grupo de estudiantes sordos frente a la lecto escritura en una Fundación para niños con VIH en Cali enero-junio. Medellín: Fundación Universitaria María Cano. Centro de Información y Ayudas Didácticas.

Ramírez, P. (2002). Programa Bilingüe de Atención Integral al Niño Sordo Menor de Cinco Años. En: Nuevos Caminos en educación Bilingüe en Colombia. Editado por Anne-Marie de Mejía y Rocío Nieves. Cali: Escuela de Ciencias del Lenguaje. Universidad del Valle.

Rodríguez, M. A. (1992). Lenguaje de Signos. Madrid: Confederación Nacional de Sordos de España y ONCE.

Rogoff, B. (1993). Aprendices del pensamiento. El desarrollo cognitivo en el contexto social. Barcelona: Paidós.

Sánchez, C. (1990). La increíble y triste historia de la sordera. Caracas: Ceprosord.

Schalock, R.L. (1999. Hacia una nueva concepción de discapacidad. En M A. Verdugo y F Jordán de Urriés (Coords). Hacia una nueva concepción de discapacidad. Salamanca: Amarú.

Skliar, C. (1998). Bilingüismo y biculturalismo: un análisis sobre las narrativas tradicionales en la educación de los sordos. Revista Brasileira de Educação, 8, 44-57.

Skliar, C., Massone, M. I. \& Veinberg, S. (1995). El acceso de los niños sordos al bilingüismo y al biculturalismo. Retrieved 2010-02-21 from http://www.culturasorda.eu/7.html

Tovar, L. A. (2004). La necesidad de planificar una norma académica en las lenguas de señas. Lengua y Habla. Mérida:Universidad de Los Andes.

Vasco, C. E. (2007). Historical evolution of number systems and numeration systems: Psychogenetic, didactical, and educational research implications. In E. Teubal , J. Dockrell, and L. Tolchinsky (eds.), Notational knowledge: Historical and developmental perspectives (pp. 13-43). Rotterdam/Taipei: Sense Publishers.

Van Cleve, J. V., \& Crouch, B. A.. (1989). A place of their own. Washington, DC: Gallaudet University Press.

Vergnaud, G. (1997). El niño, las matemáticas y la realidad. México: Trillas.

Vigotsky, L. (1981). Pensamiento y lenguaje. Barcelona: Paidós.

Vlachou, A. 1999. caminos hacia una educación inclusiva. Madrid: La Muralla. 
Wertsch, J. (1988). Vigotsky y la formación social de la mente. Barcelona: Paidós.

(Endnotes)

1 We distinguish conceptual number systems, whose basic entities are numbers, from semiotic numeration systems (also called "numbering systems"), whose basic entities are numerals. In other words, the Roman, Hindu-Arabic, finger, and dot numerals are considered numeration systems that only capture certain invariants of the conceptual structure of the natural number system (Vasco, 2007).

2 The notion of semiotic system (SS) is the more general construct; a semiotic representation register $(\mathrm{SRR})$ is a specific production-and-interpretation SS, whose products are semiotic representations (SR's), considered to be primarily external and materialized, although they can be internalized as mental images, and examined, reproduced or changed by visualization (see Duval, 1995).

3 Although somewhat analogous to Duval's use of "register" as in SRR's, the use of 'register' here refers to functional linguistic variants of speech in use, in the sense introduced by Thomas B. Reid in the 1950's, Halliday, Hasan and others in the 1960's and 70's (see in particular Halliday, 1978/1982, and Biber, 1995). For the case of arithmetic, see Vasco (2007).

$4 \quad$ Linguistic models play a different role from interpreters. Interpreters translate from oral Spanish to CSL, and vice-versa when teachers are not CSL users. Linguistic models are fluent users of the Colombian Sign-Language also somewhat versed in the subject being taught, who simultaneously complement what teachers are attempting to communicate to deaf children in their own incipient CSL.

5 In Duval's terminology, treatments are changes done to a given external SR to obtain another SR belonging to the same SSR, and conversions are changes done to an external SR belonging to a given SSR to obtain another SR belonging to another SSR. Conversions are much more powerful than treatments for the learning of number systems. 